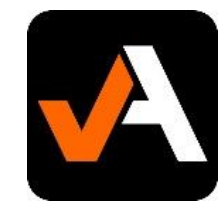

Volume: 05

Nomor : 02

Bulan : Mei

Tahun : 2019

http : //ejurnal.pps.ung.ac.id/index.php/AKSARA/index

\title{
ANALISIS PENGUASAAN SANTRI TERHADAP KITAB KUNING BAERDASARKAN BERDASARKAN POLA PEMBINAAN (STUDI KASUS PONDOK PESANTREN AL-HUDA PROVINSI GORONTALO)
}

\author{
Abd. Rasyid Kamaru \\ abdrasyidkamaru@gmail.com \\ Received: 29 Februari 2019; Revised: 12 April 2019; Accepted: 15 April 2019
}

\begin{abstract}
ABSTRAK
Pondok pesantren al-Huda provinsi Gorontalo yang didirikan pada tahun 1961 sampai dengan sekarang tetap eksis dalam kajian kitab kuning dan menggunakan sistem klasikal. Penelitian ini mengambil lokasi di pondok pesantren al-Huda provinsi Gorontalo. Data yang diuraikan dalam penelitian ini adalah deskriptif kualitatif, adapun metode yang digunakan berupa observasi, interview dan dokumentasi. Sedangkan analisis data menggunakan metode induktif, deduktif dan komparatif. Teknik pengolahan data yaitu menggunakan tiga metode yaitu: reduksi data, penyajian data dan menarik kesimpulan. Hasil penelitian ini menunjukkan bahwa penguasaan santri terhadap kitab kuning belum maksimal, maka pola yang dilaksanakan adalah memaksimalkan penguasaan santri pada mata pelajaran nahwu dan sharaf sebagai alat untuk menguasai kitab kuning. Rekomendasi penelitian ini diharapkan dapat meningkatkan kerja sama antar pihak pondok pesantren, pemerintah, masyarakat yang tampak dari sikap, perilaku, pemikiran maupun kerja sama antar pondok pesantren yang terkesan vakum selama ini.
\end{abstract}

\section{PENDAHULUAN}

Pondok pesantren jumlahnya cukup besar yang tersebar di seluruh penjuru tanah air. Jumlah para santri dari pondok pesantren kecil sampai pondok pesantren besar mencapai jutaan orang dengan jumlah kelembagaan puluhan ribu, dan jika ditambah dengan diniyah yang melakukan kegiatan proses belajar mengajar seperti, pondok pesantren jumlahnya dapat mencapai ratusan ribu, dengan jumlah santri dan masyarakat pendukungnya bisa meningkat lagi. Kalau potensi tersebut dapat dikelola dan didayagunakan dengan sebaik-baiknya melalui program pengembangan keterampilan dan penerapan alih teknologi tepat guna, maka tidak saja dapat meningkatkan nilai tambah dan kesejahteraan bagi warga pondok pesantren, tetapi juga memberikan kontribusi yang signifikan untuk menunjang keberhasilan pembangunan nasional.

Pondok pesantren merupakan lembaga pendidikan dan pengajaran Islam, di mana di dalamnya terjadi interaksi antara kyai atau ustadz sebagai guru dan para santri, dengan mengambil tempat di masjid atau di halaman-halaman asrama (pondok) untuk mengaji dan membahas buku-buku teks keagamaan karya ulama masa lalu. Buku-buku teks ini lebih dikenal dengan sebutan kitab kuning, karena di masa lalu kitab-kitab itu pada umumnya ditulis atau dicetak di atas kertas berwarna kuning.

Pondok pesantren yang ada di provinsi Gorontalo, dipahami oleh masyarakat hanya mengajarkan pendidikan keagamaan, tetapi kenyataannya seluruh pondok pesantren yang ada di provinsi Gorontalo, termasuk pondok pesantren al-Huda telah mengajarkan mata pelajaran umum, bahkan sejak kehadirannya di tahun 1961 sudah menerapkan sistem klasikal dan mengikuti kurikulum nasional sehingga pondok pesantren tersebut telah memberikan konstribusi 
kepada bangsa dan negara terutama dalam upaya meningkatkan penguasaaan santri terhadap kitab kuning.

\section{TINJAUAN PUSTAKA}

\section{Pengertian dan pola umum pondok pesantren}

Pondok adalah: rumah untuk sementara waktu, seperti: yang didirikan di ladang, di hutan dan sebagainya. "Pesantren" adalah asrama dan tempat murid-murid mengaji dan menuntut ilmu terutama yang berkaitan dengan agama Islam. Pesantren adalah tempat para santri belajar ilmu agama Islam. Kata pesantren berasal dari kata "santri" artinya murid yang belajar ilmu agama Islam. Kemudian mendapat awalan pe- dan akhiran-an menjadi pesantrian. Huruf $i$ dan an mengalami perubahan sehingga sebutan pesantrian menjadi pesantren. Disebut pesantrian atau pesantren karena seluruh murid yang belajar dipesantren tersebut dengan santri. Tidak dikenal sebutan siswa atau murid. Sebutan santri merupakan konsep baku meskipun maknanya siswa, murid atau anak didik. Sebutan santri memiliki perbedaan substansial dengan siswa atau murid. Santri hanya berlaku untuk siswa yang belajar di pondok pesantren dan obyek kajian yang dipelajarinya ilmu agama Islam. Sedangkan murid atau siswa berlaku umum. Pesantren, atau pondok, adalah lembaga yang dapat dikatakan merupakan wujud proses belajar, perkembangan sistem pendidikan dan selanjutnya ia merupakan bapak dari pendidikan Islam.

Pesantren sendiri menurut pengertian dasarnya adalah, tempat belajar para santri. Sedangkan pondok berarti tempat tinggal sedarhana yang terbuat dari bamboo. Kata Pondok mungkin berasal dari bahasa arab "funduk". Yang berarti hotel atau asrama. Pondok, adalah: rumah yang agak kurang baik. Biasanya berdinding bilik dan beratap rumbia, dan sebagainya. Lambat laun pondok-pondok berkurang diganti dengan rumah yang tidak mudah terbakar. Pondok juga berarti madrasah atau asrama (tempat mengajar dan belajar agama Islam).

Setidaknya ada 3 (tiga) hal yang paling menonjol dalam pengembangan pondok pesantren yaitu pendidikan, pengembangan sarana dan pra-sarana serta mutu pendidikan.

a. Pendidikan.

Pendidikan di pondok pesantren dalam menyusun program pembelajaran berprinsip pada halhal sebagai berikut: 1) Mengorganisasikan materi untuk dipelajari santri secara unit-unit yang terpisah, jelas bidangnya, serta relatif lebih kecil unit-unit pelajarannya sehingga mudah dikelola; 2) Interaksi antara santri dengan unit kecil pelajaran berlangsung secara bertahap; 3) Umpan balik belajar santri dapat segera diketahui untuk dikomunikasikan dengan taraf penguasaan bahan pelajaran yang telah disajikan kepada mereka; 4) Memacu diri (self-pacing) secara bertahap dalam proses penguasaan bahan pelajaran; 5) Diagram feedback (umpan balik) belajar berprograma.

b. Pengembangan sarana dan prasarana.

Pengembangan-pengembangan pendidikan pondok pesantren adalah 1) Pengembangan lembaga pendidikan dari semua akomodasi, fasilitas, sarana dan prasarananya; 2) Perubah kurikulum, yaitu perpaduan antara ilmu agama Islam dan semua alatnya, serta ilmu pengetahuan umum, yang semua dipandang sebagai ilmu barat; 3) Pengembangan metode pembelajaran, kini jarang digunakan metode wetonan maupun sorogan. Metode pembelajaran di pondok pesantren sama dengan di sekolah umum;

c. Mutu pendidikan

\section{Jurnal Ilmu Pendidikan Nonformal AKSARA}


Banyak pakar dan organisasi yang mencoba mendefinisikan kualitas (mutu) berdasarkan sudut pandangnya masing-masing. Walaupun definisi tersebut tidak ada yang diterima secara universal, tetapi terdapat beberapa kesamaan, yaitu elemen-elemen berupa usaha untuk memenuhi harapan pelanggan atau produk, jasa manusia, proses dan lingkungan dan atau merupakan kondisi yang selalu berubah. Berdasarkan elemen-elemen tersebut, Goetsch dan Davis yang dikutip oleh Tjiptono, membuat definisi kualitas yang lebih luas cakupannya, yakni "kualitas merupakan kondisi yang dinamis yang berhubungan dengan produk, jasa manusia, proses dan lingkungan yang memenuhi, atau melebihi harapan.

Definisi mutu menurut ISO 2000 dalam Erfi Ilyas, mutu adalah totalitas karakteristik suatu produk (barang dan jasa) yang menunjang kemampuannya untuk memenuhi kebutuhan yang dispesifikasikan atau ditetapkan.

Dari definisi-definisi tersebut, secara umum mutu adalah gambaran dan karekteristik secara menyeluruh dari barang atau jasa yang menunjukan kemampuannya dalam memuaskan kebutuhan yang diharapkan atau yang tersirat. Dalam konteks pendidikan di pondok pesantren, pengertian mutu mencakup: input, proses, dan output pendidikan.

\section{METODE PENELITIAN}

Penelitian ini mengambil lokasi di pondok pesantren al-Huda provinsi Gorontalo. Data yang diuraikan dalam penelitian ini adalah deskriptif kualitatif, adapun metode yang digunakan berupa observasi, interview dan dokumentasi. Sedangkan analisis data menggunakan metode induktif, deduktif dan komparatif. Teknik pengolahan data yaitu menggunakan tiga metode yaitu: reduksi data, penyajian data dan menarik kesimpulan.

\section{HASIL PENELITIAN DAN PEMBAHASAN}

Pola pembinaan santri dalam penguasaan kitab kuning di Pesantren Al Huda Gorontalo dibagi atas beberapa Peride

1) Periode madrasah al-Fatah (1929-1961)

Pembinaan kitab berpusat di rumah-rumah penduduk, di surau, salah satu rumah yang menjadi tempat berlangsungnya aktivitas ini adalah tempat kediaman H. Umar Basalama. Rutinitas aktivitas ini tergantung pada kesiapan pembina dan santri umumnya saat itu dikenal dengan pengajian atau mongadi. Aktivitas seperti ini juga tidak mengenal hari Ahad (libur), jatah waktu berdasarkan kesepakatan antara keduanya, ketika ada waktu lowong para santri mengkaji ulang tentang kandungan kitab kuning.

Kepedulian di kalangan santri terhadap kitab kuning yang tak kenal waktu patut diteladani, adapun aktifitas kajian kitab kuning di rumah santri tetap berlaku dan dilaksanakan secara bergilir. Kajian kitab kuning berlangsung secara berkesinambungan dengan kitab yang sama seperti tafsir Jalâlain dari kelas 1 sampai kelas 3, begitu pula kitab tauhid, fiqh, tarikh, mahfudzhat, untuk mata pelajaran logah, mufradât, dan khat disesuaikan dengan konsep pembina, artinya dapat diambil dari tafsir, tauhid, akhlak tidak ada kitab khusus.

2) Periode pondok pesantren al-Huda (1961 s.d Sekarang)

a) Pola pembinaan kitab kuning di pondok pesantren pada tahun 1961-1981

Dalam kurun waktu 20 tahun pondok pesantren al-Huda mengikuti kurikulum pondok pesantren Al-Khaerât Palu, baik mata pelajaran agama maupun mata pelajaran umum, dalam 
bahasan ini hanya dibatasi pada mata pelajaran yang berkaitan dengan pengkajian kitab kuning di pondok pesantren, untuk lebih jelasnya dapat dilihat pada Tabel 1 berikut:

Tabel. 1. Daftar nama pelajaran, kitab untuk tiap-tiap jenjang

\begin{tabular}{|c|c|c|c|}
\hline No & $\begin{array}{l}\text { Jenjang / } \\
\text { Mata Pelajaran }\end{array}$ & Nama Kitab & Penyusun \\
\hline A. & \multicolumn{3}{|c|}{ Madrasah Ibtidaiyah } \\
\hline & 1. Tauhid & Sulam al-Tauhid & Ibn Al-Abi Al-Hamîd \\
\hline & 2. Tajwid & Al-Qurân / Tajwid & Abdullah Asy’ari \\
\hline & 3. nahwu & Al-Ajrûmiyyah & Abdul Qohir Al-Jurjani \\
\hline & 4. sharaf & Matn al-Binâ & Abdullah Al-Danqazy \\
\hline & 5. Fiqh & Al-Mabâdi' al-Fiqhiyyah & Umar Abdul Jabbar \\
\hline & 6. Tarikh & Khulâsah Nûr al-Yaqîn & Umar Abdul Jabbar \\
\hline B. & \multicolumn{3}{|c|}{ Madrasah Tsanawiyah } \\
\hline & 1. Tauhid & Sulam al-Tauhid & Ibn Al-Abi Al-Hamîd \\
\hline & 2. Tajwid & Al-Qurân / Tajwid & Abdullah Asy'ari \\
\hline & 3. Akhlak & Akhlâq li al-Banîn & Umar Ahmad Baraja \\
\hline & 4. nahwu & Al-Ajrûmiyyah & Abdul Qohir Al-Jurjani \\
\hline & 5. sharaf & Matn al-Binâ & Abdullah Al-Danqazy \\
\hline & 6. Fiqih & Fath al-Qarîb & Umar Abdul Jabbar \\
\hline & 7. Tafsir & Tafsîr al-Jalâlain & $\begin{array}{l}\text { Djalaluddin Al-Mahally } \\
\text { Djlaluddin Assuyuty }\end{array}$ \\
\hline & 8. Hadis & Riyâdh al-Shâlihîn & Imam Al-Nawawy \\
\hline & 9. Tarikh & Khulâsa Nûr al-Yaqîn & Umar Abdul Jabbar \\
\hline C. & \multicolumn{3}{|l|}{ Madrasah Aliyah } \\
\hline & 1. Tauhid & $\begin{array}{l}\text { - Sulam al-Tauhid } \\
\text { - Al-Jawâhir al-Kalâmiyyah }\end{array}$ & $\begin{array}{l}\text { - Ibn Al-Abi Al-Hamîd } \\
\text { - Tahir Ibn Shaleh Al-Jazair }\end{array}$ \\
\hline & 2. Tajwid & Al-Qurân / Tajwid & Abdullah Asy'ari \\
\hline & 3. Akhlak & Akhlâq li al-Banîn & Umar Ahmad Baraja \\
\hline & 4. nahwu & $\begin{array}{l}\text { - Al-Ajrûmiyyah } \\
\text { - Alfiya Ibn Malik }\end{array}$ & $\begin{array}{l}\text { - Abdul Qohir Al-Jurjani } \\
\text { - Jamaluddin Muhammad Ibn } \\
\text { Abdullah Ibn Malik }\end{array}$ \\
\hline & 5. sharaf & Al-Amsilat al-Tasrifiyyah & Muhammad Ma'sum Ibn Aly \\
\hline & 6. Fiqih & Fath al-Qarîb & Umar Abdul Jabbar \\
\hline & 7. Tafsir & Tafsîr al-Jalâlain & $\begin{array}{l}\text { - Djalaluddin Al-Mahally } \\
\text { - Djlaluddin Assuyuty }\end{array}$ \\
\hline & 8. Hadis & Riyâdh al-Shâlihîn & Imam Al-Nawawy \\
\hline & 9. Tarikh & Khulâsa Nûr al-Yaqîn & Umar Abdul Jabbar \\
\hline & 10. Bahasa Arab & Tamyîz & Abaza \\
\hline
\end{tabular}

Sumber: pondok pesantren al-Huda 2014

160 Jurnal Ilmu Pendidikan Nonformal AKSARA 
Dari Tabel 1 terlihat bahwa mata pelajaran pondok pesantren Al-Huda baik dari madrasah ibtidaiyah, madrasah tsanawiyah, maupun madrasah aliyah menggunakan kurikulum Al-Khaerât Palu, menurut dr. Burhanudin Umar bahwa, tidak saja kurikulum dari Al-Khaerât Palu tetapi umumnya pengasuh/ustadz juga berasal dari Al-Khaerât seperti Yakub Lahambu, Asiah Marjenna, Nur Uyun, Mahmud Patimbang, Sayyid Yasin Al-Hasni kecuali KH. Abd. Gafir Nawawi berasal dari Cirebon Jawa Tengah.

Para pengasuh yang didatangkan dari Palu, seluruhnya merupakan murid dari Habib Idrus bin Salim Al-Jufry. Santri yang tinggal di pondok pesantren atau yang di luar disebut dengan murid dan Abnâulkhairât dan Habib Idrus dikenal dengan Guru Tua. Banyak santri yang memiliki kemampuan membaca kitab di antaranya Nikma Sabaya, Aisa Al-Masyhur, Maryam Fathan, Fauziah Helingo, Zainab Saleh, Hapsah Saleh, Marwan Saleh, Awaludin Karim, Salahuddin, Mukhtahir, Lili Tumulo, Hasan T. Aja, Sartin Muhammad, Marzuk Harun, KH. Muhammad Abu Bakar, KH. Lukman Katili, Ismail H. Botone, Raflin Kamumu, Hamdan Ladiku, dan Erwin Thaib.

b) Pola pembinaan kitab kuning di pondok pesantren pada tahun $1981 \mathrm{~s} / \mathrm{d}$ sekarang menggunakan kurikulum sesuai dengan Tabel 1.

Dari uraian di atas, tampak benang merah antara pola yang diterapkan pada tahun 1961-1981 dan tahun 1981 s.d sekarang. Pada tahun 1961-1981 titik beratnya menghafal dan menguasainya baik pada saat belajar, ujian semester, maupun ujian akhir pondok. Pola yang dilaksanakan pada tahun 1981 s.d sekarang tidak difokuskan lagi pada menghafal, tetapi bagaimana santri mengkaji kitab dan menerapkannya dalam kehidupan sehari-hari, serta mampu memanfaatkan teknologi.

Pengasuh kitab kuning pada masa ini pada Ponpes Al Huda terdiri kurang lebih 9 orang. Di samping itu santri yang mampu membaca kitab lebih dari 5 orang, adapun santri yang Hafidz 20 Juz juga lebih dari 3 orang.

\section{PENUTUP}

Berdasarkan hasil penelitian ini disimpulkan bahwa: Sistem pendidikan di pondok pesantren Al-Huda Provinsi Gorontalo. Pola pembinaan pondok pesantren al-Huda di provinsi Gorontalo menunjukan hasil yang menggembirakan karena keunikan sistem pendidikan di pondok pesantren seperti pondok pesantren al-Huda berfokus pada keseimbangan pencapaian IPTEK dan IMTAQ hal ini dapat dilihat dari penerapan 3 model kurikulum yaitu kurikulum nasional, kurikulum kementrian agama, dan kurikulum pondok pesantren.

\section{Daftar Pustaka}

Azra Azumardi, Pendidikan Islam Tradisi dan Modernisasi di Tengah Tantangan Milenium III, Jakarta: Kencana, 2012.

Basri Hasan, Saebani. Beni Ahmad, Ilmu Pendidikan Islam (Jilid II), Bandung: CV. Pustaka Setia, 2010.

Departemen Agama RI, Pola Pembelajaran di pesantren, Jakarta: Direktorat Jenderal Kelembagaan Agara Islam Direktorat Pendidikan Keagamaan dan pondok pesantren, 2003.

Departemen Pendidikan Nasional, Ensiklopedi Islam Jilid 4, Jakarta: PT. Ichtiar Baru Van Hoeve, Cet. Ke-10, 2002.

Hanafiyah Nanang, Cucu Suhana, Konsep Strategi Pembelajaran, Cet1; Bandung : PT. Refika Aditama, 2009. 
http://nidafijriyah.blogspot.com/2012/05/normal-0-false-false-false-in-x-none-

ar_22.html, Partisipasi Masyarakat dalam Proses Pendidikan, Strategi Peningkatan Masyarakat, diakses pada tanggal 22 Maret 2014.

Nata H. Abuddin, Sejarah Pertumbuhan Dan Perkembangan Lembaga Pendidikan Islam di Indonesia, Jakarta: PT. Grasindo, 2001.

Poerwadarminta WJS, Kamus Umum Bahasa Indonesia Edisi Ketiga, Jakarta: Departemen Pendidikan Nasional, Balai Pustaka, 2006.

Qomar, Mujamil, pesantren Dari Transformasi Menuju Demokratisasi Institusi, Jakarta : Erlangga, 1996.

Roham Abujamin, Ensiklopedi Lintas Agama, Jakarta: PT. Intermasa, 2009.

Saputra Budi, Aneka Keguruan, Bandung: PT. Rafika Aditama, 2009.

Saridjo Marwan, Pendidikan dari Masa ke Masa, Jakarta: Yayasan Ngali Aksara dan Al Manar Press, 2011.

Yahiji, Kasim, Cara Mudah Memahami Kitab Gundul, Strategi Pembelajaran Kitab Kuning di pondok pesantren, Gorontalo: Sultan Amai Press IAIN Sultan Amai Gorontalo, 2011. 